\title{
Increasing the safety against scuffing of additive manufactured gear wheels by internal cooling channels
}

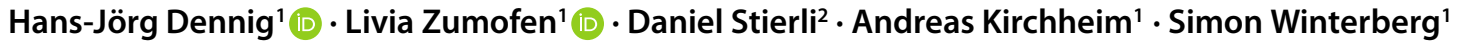

Received: 25 March 2021 / Accepted: 5 July 2021 / Published online: 13 September 2021

(c) The Author(s) 2021

\begin{abstract}
The layer-by-layer principle of the additive manufacturing (AM) technology of Laser-Powder-Bed-Fusion (LPBF) creates new opportunities in the design and manufacturing of efficient gear components. For example, integrating a cooling system can increase the safety against scuffing or reduce the amount of required lubrication and thus the splashing losses. Quenched and tempered steels or case-hardened steels are commonly used in the fabrication of gear components. However, the availability of these alloys for LPBF processing is still limited. The development of suitable LPBF metal gears (with a Gear Research Centre (FZG) type A geometry) out of quenched and tempered 30CrNiMo8 steel with internal cooling channels shows the possibility of significantly increasing the safety factor against scuffing. This work includes the development of a suitable cooling strategy, material development, the setup of a suitable test infrastructure and the analysis of the LPBF gears tested for scuffing.
\end{abstract}

\section{Erhöhung der Fresssicherheit von additiv gefertigten Zahnrädern durch interne Kühlkanäle}

\section{Zusammenfassung}

Das Prinzip der Schichttechnologie der additiven Fertigungstechnologie Laser-Powder-Bed-Fusion (LPBF) eröffnet vollkommen neue Möglichkeiten in der Konstruktion und Fertigung von effizienten Getriebekomponenten. So kann z.B. ein integriertes Kühlsystem die Sicherheit gegen Fressen erhöhen oder die Menge der benötigten Schmierung und damit die Planschverluste reduzieren. Vergütungs- und Einsatzstähle sind häufig verwendete Werkstoffe für Getriebekomponenten. Die Verfügbarkeit dieser Legierungen für die additive Fertigung ist jedoch begrenzt. Die Entwicklung von geeigneten LPBF-Metallzahnrädern (FZG-A-Geometrie) aus dem Vergütungsstahl 30CrNiMo8 mit innenliegenden Kühlkanälen wird hier beschrieben. Es zeigt die Möglichkeiten auf, wie die Sicherheit gegen Fressen mit innenliegenden Kühlkanälen signifikant erhöht werden kann. Dies umfasst die Entwicklung einer geeigneten Kühlstrategie, die Werkstoffentwicklung, den Aufbau einer geeigneten Prüfinfrastruktur und die Analyse der auf Fressen getesteten LPBF-Zahnräder.

\section{Introduction and motivation}

Open Access This article is distributed under the terms of the Creative Commons Attribution 4.0 International License (http://creativecommons.org/licenses/by/4.0/), which permits unrestricted use, distribution, and reproduction in any medium, provided you give appropriate credit to the original author(s) and the source, provide a link to the Creative Commons license, and indicate if changes were made.

$\triangle$ Hans-Jörg Dennig

hans-joerg.dennig@zhaw.ch

1 Centre for Product and Process Development, ZHAW Zurich University of Applied Sciences, Winterthur, Switzerland

2 Renk-Maag GmbH, Winterthur, Switzerland
Transmission components must be made lighter and more efficient $[1,2]$. Spur gears are a central element of many gear systems [3, 4]. Designs that allow smaller moments of inertia and optimised cooling, lubrication and tooth contact can increase the efficiency of gears [1]. Gears produced using the LPBF process $^{1}$ with typical gear steels offer great potential in increasing efficiency. In addition to the man-

\footnotetext{
1 Additive manufacturing (AM) includes many new technologies that enable the layer-by-layer creation of complex structures based on three-dimensional models. Laser Powder Bed Fusion (LPBF) is one of the most common AM processes for metals.
} 


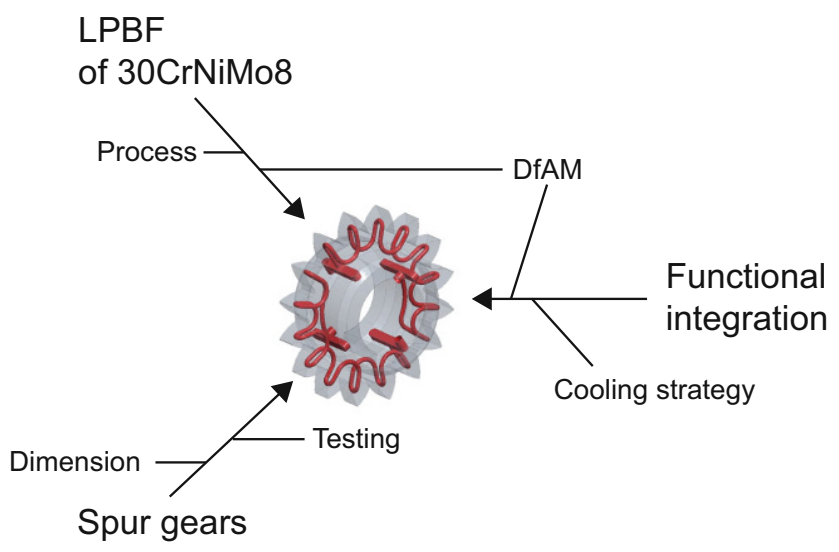

Fig. 1 Knowledge areas for gears with internal cooling channels

ufacturing of force-flow-optimised lightweight structures, e.g., those used in toolmaking, the integration of internal channel structures enables new opportunities for optimisation [5, 6]. In particular, the design of injection moulds utilises conformal cooling for process optimisation [7].

A high degree of efficiency in power transmission and, at the same time, a high power density of the gear elements are essential [8]. A suitable lubrication system, such as an oil bath or injection lubrication, used to dissipate the heat generated at the tooth contact simultaneously creates load-independent losses, e.g., due to splashing [9]. If the heat can be removed, e.g., through internal cooling channels, the load-independent losses can be reduced, and the efficiency can be increased at the same time $[1,10]$. Such cooling channels can only be manufactured conventionally with great effort or not at all. AM offers both cost and performance benefits [11].

The following paper shows the possibilities for manufacturing such a gear and demonstrates its effectiveness. Success of this investigation is not dependent on determining the safety factor against scuffing of the proposed material according to the standard; instead, it depends on the principle effect of the internal cooling against scuffing.

To manufacture such a gear, interdisciplinary knowledge is needed (Fig. 1). When selecting a new material to be manufactured, the correct LPBF process parameters must be developed to achieve the required material properties. The process stability and the quality of the results also closely depend on the geometry design. Design for AM (DfAM) plays a decisive role here [12]. For example, from certain downskin angles, support structures must be integrated, or certain cooling channel diameter:length ratios must be maintained [13]. If the diameter of the cooling channel is too large, the tooth is weakened too much. If it is too small, less heat can be extracted in the isobaric system. In other words, the selection of a suitable tooth geometry and the associated test procedures are very im- portant. The aim of this study is to clarify the influence of internal cooling on the safety against scuffing.

Although the widely used case-hardening steel $16 \mathrm{MnCr} 5$ has largely been successfully produced by the LPBF process and often tested for its suitability in gears [14], the focus in the application described is on quenched and tempered 30CrNiMo8 steel (1.6580). It exhibits high strength and toughness. With a tensile strength of $1250 \mathrm{MPa}$ and a tensile/compression fatigue strength of $500 \mathrm{MPa}$, quenched and tempered $30 \mathrm{CrNiMo} 8$ steel can be used in general engineering for high mechanical requirements [15]. This is the case, for example, in large gear manufacturing, quenched and tempered 30CrNiMo8 steel is chosen due to its cost-effective and simple production, easily controllable heat treatment process, good running-in properties and high resistance to tooth root fracture. This material is also suitable for gear pairings with a hardened pinion, as is common in planetary gears, for example. The required mechanical properties of the quenched and tempered $30 \mathrm{CrNiMo} 8$ steel are obtained, in addition to its alloying constituents, by a purely thermal process [16]. In addition, quenched and tempered 30CrNiMo8 steel can be nitrided to further improve the application properties of the component.

Despite the numerous data sheets and standards for the conventional production of quenched and tempered $30 \mathrm{CrN}$ iMo8 steel and its processing, this material has so far been considered a new material in AM. There are very few research studies [30]. The reason for the rare use of this quenched and tempered steel is that it is fairly difficult to process. Like many other case-hardened or quenched and tempered steels, it is sensitive to cracking and difficult to weld or to produce using the LPBF process [17].

\section{State of the art}

During operation, gearwheels are exposed to mechanical, tribological, thermal and chemical stresses. During operation, the normal force acting on the tooth flank travels along the line of action [4]. As a result, the tooth flank surface and the tooth root are subjected to time-dependent loads. The latter is not discussed further in the following article.

The tooth flank is primarily exposed to pressure and friction with simultaneous kinematic movements [8]. In the process, various types of damage can occur on the flank, such as surface disruption, abrasion, adhesion and chemical reactions.

In this case, scuffing is due to the wear mechanism of adhesion. Even a brief overload can lead to damage. The damage is characterised by the roughness aligned in the direction of the tooth depth. A differentiation is made between warm and cold scuffing. Scuffing without the influence of temperature is called cold scuffing, which occurs mainly at 


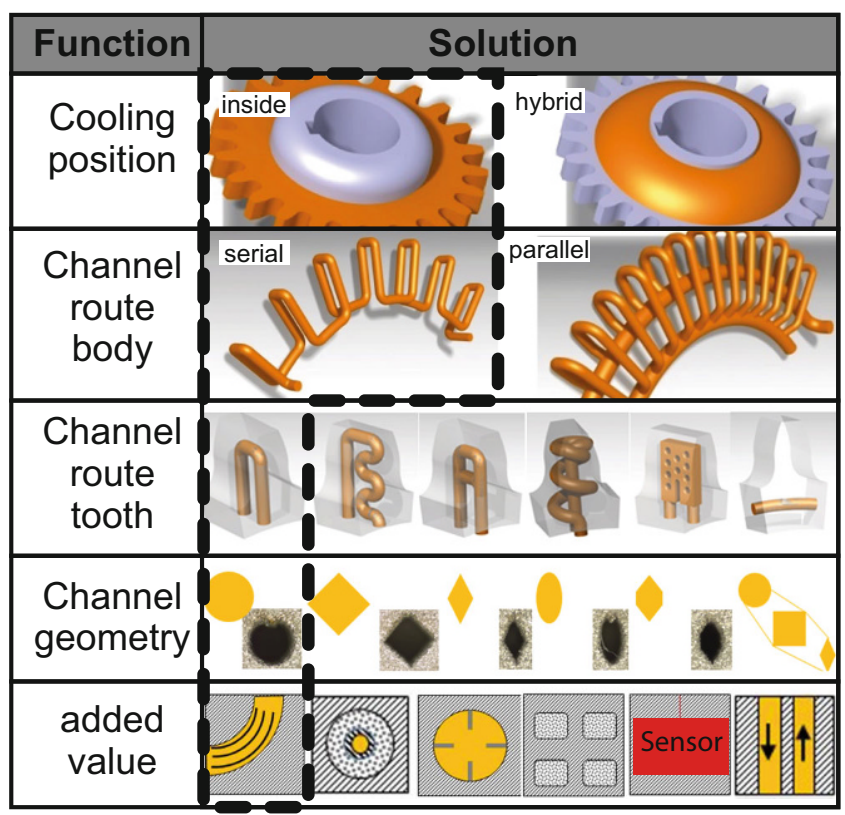

Fig. 2 Morphology of the cooling strategy and selected combination (framed in dotted black)

low speeds. Warm scuffing is the form that occurs more frequently. It occurs at high sliding speeds and pressures. As a result of the increased stress, local temperature increases occur, which leads to the lubricant film tearing off or vaporizing.

The calculation of the scuffing load capacity is carried out according to DIN 3990-4 [18]. In comparison to the tooth root safety and flank safety, the scuffing load capacity is time independent. Therefore, the time to scuffing remains unknown. The gear material, lubricant, surface condition of the tooth flanks, sliding speed, load, etc., have an influence on the risk of scuffing. The reason for the breakdown of the lubricant film and the resulting wear phenomenon of scuffing is the high surface temperatures on the tooth flank [19]. Due to the awareness of the temperature dependency, two calculation methods are used to determine the risk of scuffing. The integral temperature method uses a weighted average of the surface temperature along the line of action. The flash temperature method uses a variable temperature along the line of action. The two calculation methods are to be used side by side, whereby experience should be considered to determine which method is better suited to the practical needs [18]. The flash temperature method tends to be used in turbo transmission construction and is therefore not considered further in the following application.

According to [18], the calculated safety against scuffing $\mathrm{S}_{\mathrm{ints}}$ of the integral temperature is as follows:

$S_{\text {intS }}=\frac{\vartheta_{\text {insS }}}{\vartheta_{\text {int }}} \geq S_{\text {Smin }}$

$S_{\text {int S }}=$ calculated safety against scuffing

$S_{\mathrm{Smin}}=$ minimum required safety against scuffing

$\vartheta_{\text {inss }}=$ scuffing integral temperature $\left({ }^{\circ} \mathrm{C}\right)$

$\vartheta_{\text {int }}=$ integral temperature $\left({ }^{\circ} \mathrm{C}\right)$

The scuffing integral temperature $\vartheta_{\text {ins } s}$ is defined as the temperature at which scuffing occurs above the integral temperature. The scuffing integral temperature of a mineral oil
Fig. 3 Parallel and serial arrangements and the test setup with a test gear wheel

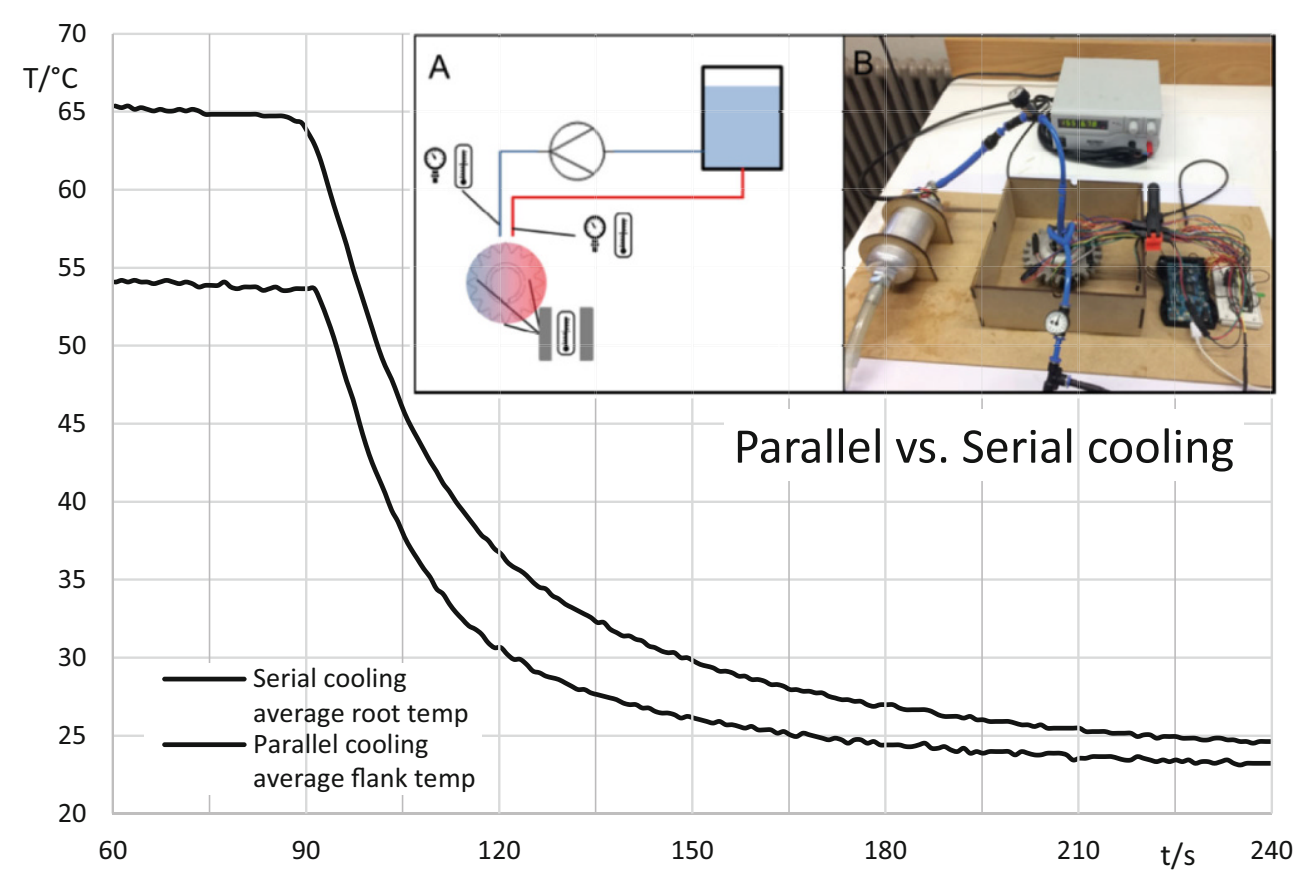


material system can be roughly determined with equation (2):

$\vartheta_{\text {ins }} \approx \vartheta_{\mathrm{MT}}+X_{W \text { relT }} \times C_{2} \times \vartheta_{\text {fla int T }}$

$\vartheta_{\mathrm{MT}}=\quad$ test bulk temperature (FZG test $\left.\mathrm{A} / 8,3 / 90\right)\left({ }^{\circ} \mathrm{C}\right)$

$X_{\text {WrelT }}=$ relative welding factor $($ FZG test $\mathrm{A} / 8,3 / 90)$

$C_{2}=\quad$ weighting factor for cylindrical gears $\left(\mathrm{C}_{2}=1.5\right)$

$\vartheta_{\text {fla int } \mathrm{T}}=$ mean flash temperature of the test gear (FZG test $\mathrm{A} / 8,3 / 90)\left({ }^{\circ} \mathrm{C}\right)$

The determination of the scuffing integral temperature refers to tests carried out with a combination of the same lubricant and a material with a different heat treatment or surface finish. Values for the test torque, which is included in $\vartheta_{\text {fla int T, }}$ can be found in the standard DIN 3990-4.

The basic equation of integral temperature $\vartheta_{\text {int }}$ is defined according to equation (3).

$\vartheta_{\text {int }} \approx \vartheta_{M}+C_{2} \times \vartheta_{\text {fla int }}$

$\vartheta_{M}=$ bulk temperature $\left({ }^{\circ} \mathrm{C}\right)$

$\vartheta_{\text {fla int }}=$ mean flash temperature $\left({ }^{\circ} \mathrm{C}\right)$

Equation (3) shows that by reducing the bulk temperature, the safety against scuffing can be reduced. It is known from practical investigations that scuffing can be expected with a high probability when $S_{\text {int }} \leq 1$. With a calculated safety between 1 and 2, scuffing is not to be expected if the gearbox is run accurately, the load-carrying profile is good and the assumptions are correct. With a calculated safety $>2$, it can be assumed that scuffing will not occur [19]. The scuffing load capacity test is ideally a running test according to ISO 14635 [20].

In this process, standardised FZG type A gears are subjected to specific load stages and checked at specific time intervals or cycles. The tooth flank contact pattern is analysed, and the damage progress is documented. Ideally, the gears are weighed after each load stage. The damage load stage is characterised by a sudden increase in the change in mass. The particular test is used to determine the so-called load stages of an oil. The smaller the load level is, the lower the safety against scuffing.

\section{Cooling strategy}

The route and design of the cooling channels are influenced by the following factors: size and cross-section, position in the tooth or gear, inlets and outlets. The larger the crosssection is, the better the heat transfer and the powder re- moval. The smaller the cross-section is, the lower the critical stresses in the tooth.

The search for a possible cooling strategy can be classified into finding main functions and their solutions (Fig. 2). If the cooling channels are inside the gear, they can efficiently cool the teeth. Another strategy would be to build them on the spur sides. Such hybrid designs are often used for cost reasons [11] and can considerably reduce production times. This also makes appropriate material pairings between the gearwheel and the applied cooling channels possible.

The next key function defines the flow principle: to connect several teeth, a serial or a parallel flow can be chosen. These two forms of flow are fundamentally different and have specific characteristics that affect all parts of the entire system. In a serial flow, all the teeth are connected in series through a continuous channel. In a parallel flow, two support channels extend the inflow and outflow so that each tooth is passed through with an independent channel [1].

The simplest variant for the channel course in the tooth is an arch shape. It could also be meandering, spiral, distributed, flat or only in the root of the tooth. A course perpendicular to the tooth width is also possible but weakens the tooth significantly with modules $<10 \mathrm{~mm}$.

Different channel cross-sections can be produced. In addition to circles and squares, rhombi, ellipses and combinations of these basic shapes are also possible. Depending on the positioning of the gear wheel in the manufacturing process, there will be overhangs in the channel cross-section. Here, rhombic elements can be used to avoid supports and improve surface roughness.

$\mathrm{AM}$ can be used to realise further functions or function optimisation in a cost-neutral way, thus exploiting the potential of the component. To optimise the heat distribution in the component, it is possible to adjust the heat transfer in the duct environment. For this purpose, a powdery shell can be created for partial insulation, or a gaseous shell can be created with air for better insulation. In addition, lamellas can increase the contact surface with the fluid and thus the heat transfer. Powdery inclusions have a vibration-damping effect and can also be used selectively [21].

As with heat exchangers, in the duct routing of two intersecting ducts, a distinction can be made between co-current and counter-current flow. To homogenise the temperature distribution and therefore to counteract heating with increasing duct length, a duct cross-section with two opposing flows is conceivable. To minimise the pressure loss in flow channels, the largest possible radii are proposed: an extreme would be guide vanes in the duct curves. For further optimisation of homogeneous cooling, bionic approaches can also be implemented [22]. In addition to almost any complex channel design, sensors can be integrated into the component directly during manufacturing [23]. 

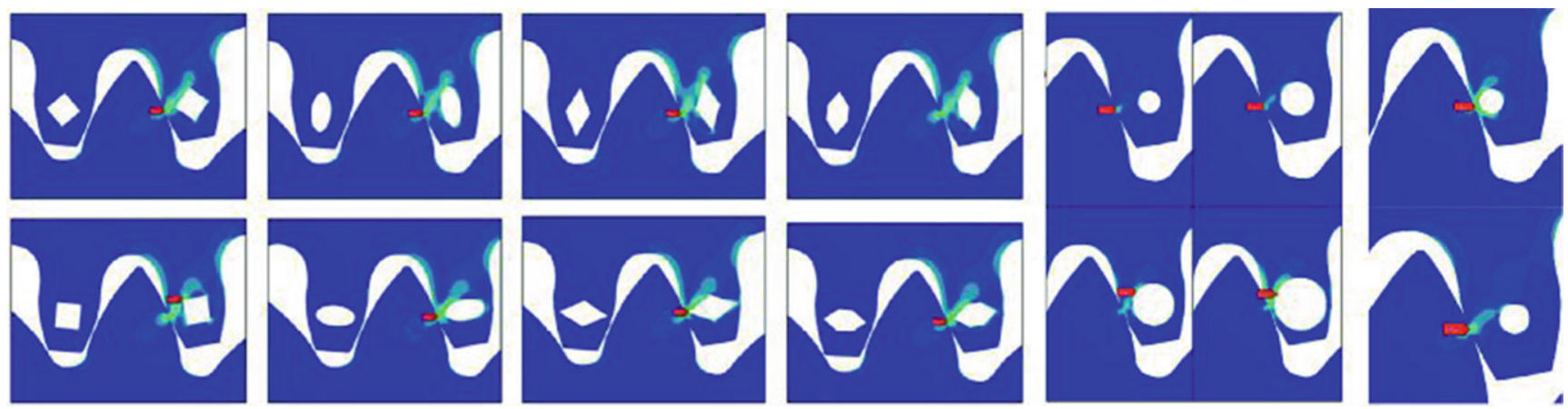

Fig. 4 Extract from the FEM parameter study showing the effect of various channel shapes and positions on the stress distribution (Visualisation on an example gear wheel)
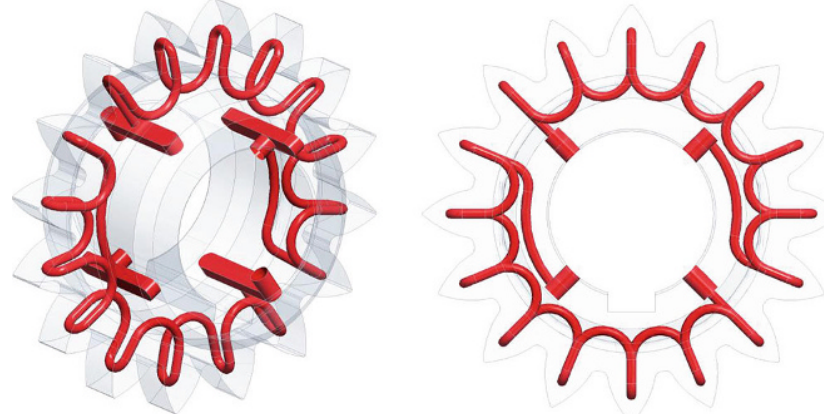

to wider gears is directly possible. If the tooth size is reduced to a module of $3.5 \mathrm{~mm}$, the developed concepts only have to be scaled. Scaling is necessary to ensure a sufficient distance between the channel and the tooth flank. It is not possible to scale the existing concepts for a gear with a module $\leq 2 \mathrm{~mm}$; this would result in channel crosssections that are too small. In this case, the manufacturability and powder removal quickly reach their limits. Special solutions are therefore required.

Fig. 5 Illustration of the serial channel path

For the selection and evaluation of the possible combinations, the following evaluation criteria were used: heat transfer, flow properties, manufacturability and powder removal. On the basis of these criteria, the combination shown in Fig. 2 was chosen for further investigation. The heat transfer is more uniform in a parallel flow, but depending on the feed line, complete powder removal is often not guaranteed. In addition, it can be difficult in practice to achieve an even flow through each tooth. Therefore, a serial flow was chosen in the present project. Computational fluid dynamics (CFD) analyses and pre-tests comparing serial and parallel flow structures show their similar behaviour. For each principle, a test gear was heated to a certain temperature and then cooled with a constant volume flow using the relative internal cooling channels (Fig. 3). As expected, the pressure loss is significantly lower in the parallel pattern.

A circular shape with a diameter of $2 \mathrm{~mm}$ centred in the tooth is chosen as the channel cross-section. A finite element method (FEM) parameter study for other cross-sectional positions and diameters shows that the circular crosssection is advantageous (Fig. 4). Various loads and boundary conditions of the gear teeth (Size, symmetry, meshing, etc.) influence performance significantly. The removal of the powder, the surface quality of the channel walls, and the position in the installation space also play a role.

The finished cooling channel is shown in Fig. 5. The developed concepts are placed at a FZG type A gear with module of $4.5 \mathrm{~mm}$ and a gear width of $10 \mathrm{~mm}$. A transfer

\section{Test object}

A spur gear pair is developed for the running test to check the scuffing load capacity (Table 1). The spur gear pair consists of the driving LPBF pinion (Fig. 5 and 6) and a conventionally manufactured gear. FZG type A gears are used for the running test. This type of gearing has a length of engagement that is shifted in the direction of the tooth crest [8]. This displacement of the length of engagement causes a higher thermal load on the tooth flank, which causes scuffing.

Compared to standard FZG type A gears, the tooth widths of the tested gears are reduced to $10 \mathrm{~mm}$ on the pinion. The reason for this is the performance achievable by the test rig used compared to the safety against scuffing.

\section{Manufacturing}

The subjects of the analysis are gears made of quenched and tempered 30CrNiMo8 steel, whose chemical composition is within the standard according to DIN EN 10083 [24]. Fig. 7 shows the manufacturing process of the tested AM gears. The heat treatment included the hardening at $850^{\circ} \mathrm{C}$, quenching in oil and tempering at $560^{\circ} \mathrm{C}$. To achieve reasonable material properties in the LPBF process, a highquality powder material and complex parameter studies are essential. For the present contribution, a Renishaw AM400 
Table 1 Details of the FZG type A test gears for the FZG scuffing test

\begin{tabular}{llll}
\hline Dimension & Symbol & Numerical Value & Unit \\
\hline Centre distance & $\mathrm{a}$ & 91.5 & $\mathrm{~mm}$ \\
Tooth width pinion & $\mathrm{b}_{1}$ & 10 & $\mathrm{~mm}$ \\
Tooth width wheel & $\mathrm{b}_{2}$ & 20 & $\mathrm{~mm}$ \\
Module & $\mathrm{m}$ & 4.5 & $\mathrm{~mm}$ \\
Number of teeth pinion & $\mathrm{z}_{1}$ & 16 & - \\
Number of teeth wheel & $\mathrm{z}_{2}$ & 24 & - \\
Pressure angle & $\alpha$ & 20 & $\circ$ \\
Helix angle & $\beta$ & 0 & $\circ$ \\
Grinding & Standard with profile grinding machine \\
Tooth correction & None &
\end{tabular}

HT laser melting system was used, which was equipped with a $400 \mathrm{~W}$ SPI fibre laser. The AM400 was retrofitted with a high temperature (HT) baseplate heating system, which was used to heat the baseplate up to $300^{\circ} \mathrm{C}$ for each experiment.

A previous study revealed promising mechanical properties of the $30 \mathrm{CrNiMo} 8$ and a high relative when processed with LPBF [25]. The yield strength and tensile strength of the quenched and tempered specimens were 1009-1016 MPa and 1094-1098 MPa [25], respectively, which are comparable with the bulk material with a similar heat treatment $[25,26]$. Additionally, the elongation at break of $14.2-16.9 \%$ (quenched and tempered) is in line with values presented in the relevant literature [25, 26]. The notch impact tests revealed remarkably high impact energies of 99-109 J for the LPBF-processed 30CrNiMo8 in the quenched and tempered states compared to the bulk material [25], indicating high ductility.

All gears are manufactured horizontally (see build-up direction "z" in Fig. 7). The staircase effect is present in all layer-additive processes [27]. The thickness of the layer can influence the shape of the steps, but the steps are unavoidable. Due to this "inaccurate" dimensional accuracy, an allowance of $1 \mathrm{~mm}$ (at the flanks $0.5 \mathrm{~mm}$ ) is added.

The layered structure of the components results in direction- and position-dependent (anisotropic) material properties [28]. The strongest anisotropy is observed in the mechanical properties such as the tensile strength and yield strength [29]. However, since all wheels are quenched and tempered, hardly any differences in strength are visible [25].

The surface quality of the LPBF process is a key issue regarding fatigue, due to the notching effect, in particular, in areas where no finishing is possible and high cyclic loads are expected. The average roughness value Ra depends on the downskin angle. In the present case, it is therefore necessary that all the outer surfaces are reworked. Furthermore, the powder needs to be removed from internal channels with air pressure, suction techniques and ultrasonic cleaning.
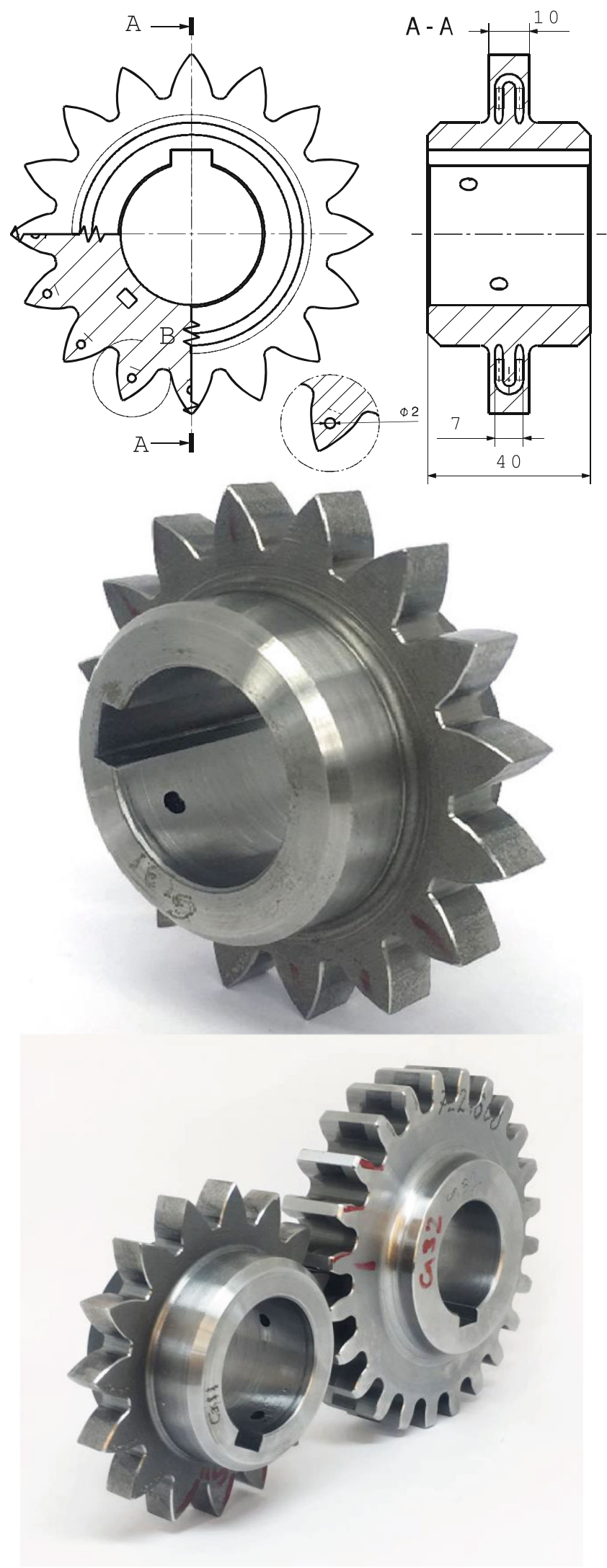

Fig. 6 Technical data of the FZG type A gear with internal cooling channels; pinion gear and gear pair 
Fig. 7 Manufacturing process of AM gears with internal cooling

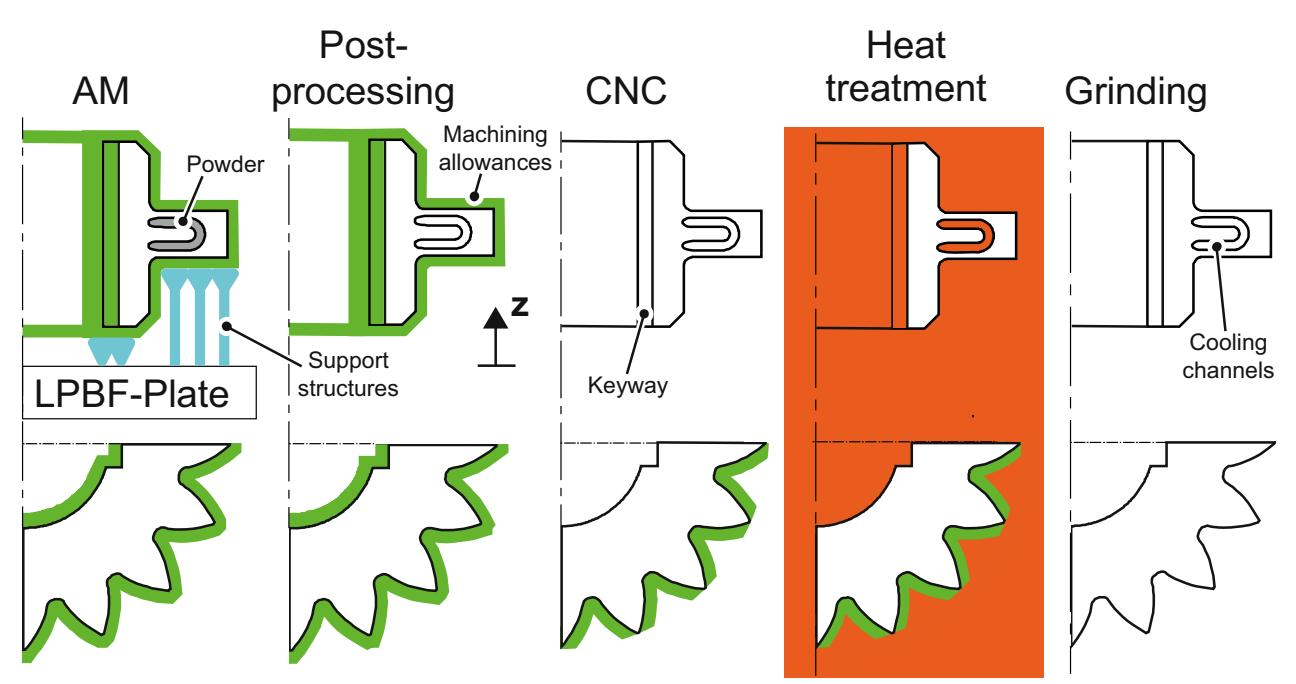

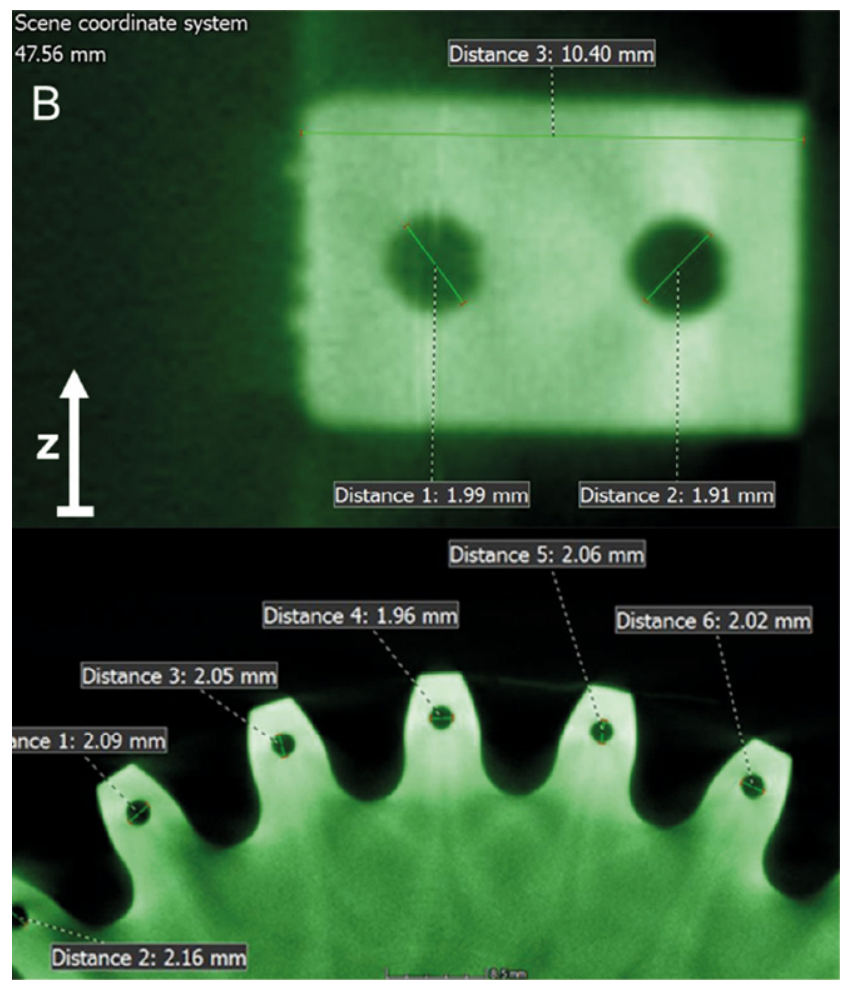

Fig. 8 CT scans to check the cross-section of a sample gear (FZG-A $\mathrm{z}_{2}=24$ ) with internal channels

Subsequently, all the surfaces except the tooth flanks are machined, and the keyway is machined. In the subsequent heat treatment, the material is hardened and tempered. Finally, the flanks are ground.

For quality control, computer tomography (CT) analysis is carried out on LPBF made gears (Fig. 8). Various cooling channel geometries were investigated according to Fig. 2. The geometry of an FZG-A counter gear $\left(\mathrm{z}_{2}=24\right)$ was used since the teeth are narrower compared to the FZG-A pinion gear, and thus the integration of the cooling channels is more difficult. The complete channel formation, defects, powder removal, dimensional accuracy of the channel cross-section and shape of the overhangs are checked. All the channel cross-sections have a circular contour. No deformations or defects in the overhang area are found. All deviations of the channel geometry are within the measurement accuracy of $150 \mu \mathrm{m}$. The internal structures are clearly visible. A detailed examination of the channels allows an assessment of the defect-free shape. No occlusions with solidified material or sticking powder can be detected. In all channels that are considered critical for powder removal, the powder has been completely removed.

\section{Test setup}

The test setup is a $19.5 \mathrm{~kW}$ non-mechanically closed loop test rig with a centre distance of $91.5 \mathrm{~mm}$ (Fig. 9). The pinion gear is equipped with cooling channels, the counter gear without cooling channels. One pair of gears and its opposite flanks by turning the gears around are used. Three gear sets are used for the tests, with which six tests (three with cooling, three without cooling) are executed for the load levels. With an additional pair of gears, pre-tests could be made and the test bench run-in. Due to the test rig characteristics, the tests are carried out in accordance with DIN ISO 14635-1 [20]. The aim is not to perform scuffing tests of oils or certain materials according to the standard but to show the effect of the internal cooling of the gears. As mentioned above, the FZG type A gear is cooled from the inside with a low-viscosity oil with a cooling temperature of $30^{\circ} \mathrm{C}$ and operated against a conventionally manufactured gear. Due to the gear ratios and the given engine power, the pinion is $b=10 \mathrm{~mm}$ wide and is driven at $2350 \mathrm{rpm}$. Wider teeth require higher torques. Lower speeds result in lower sliding speeds and a higher safety against scuffing. 
Fig. 9 Test rig with internal cooling for the pinion gear and minimum quantity lubrication for the gear box
Fig. 10 Results of the scuffing tests
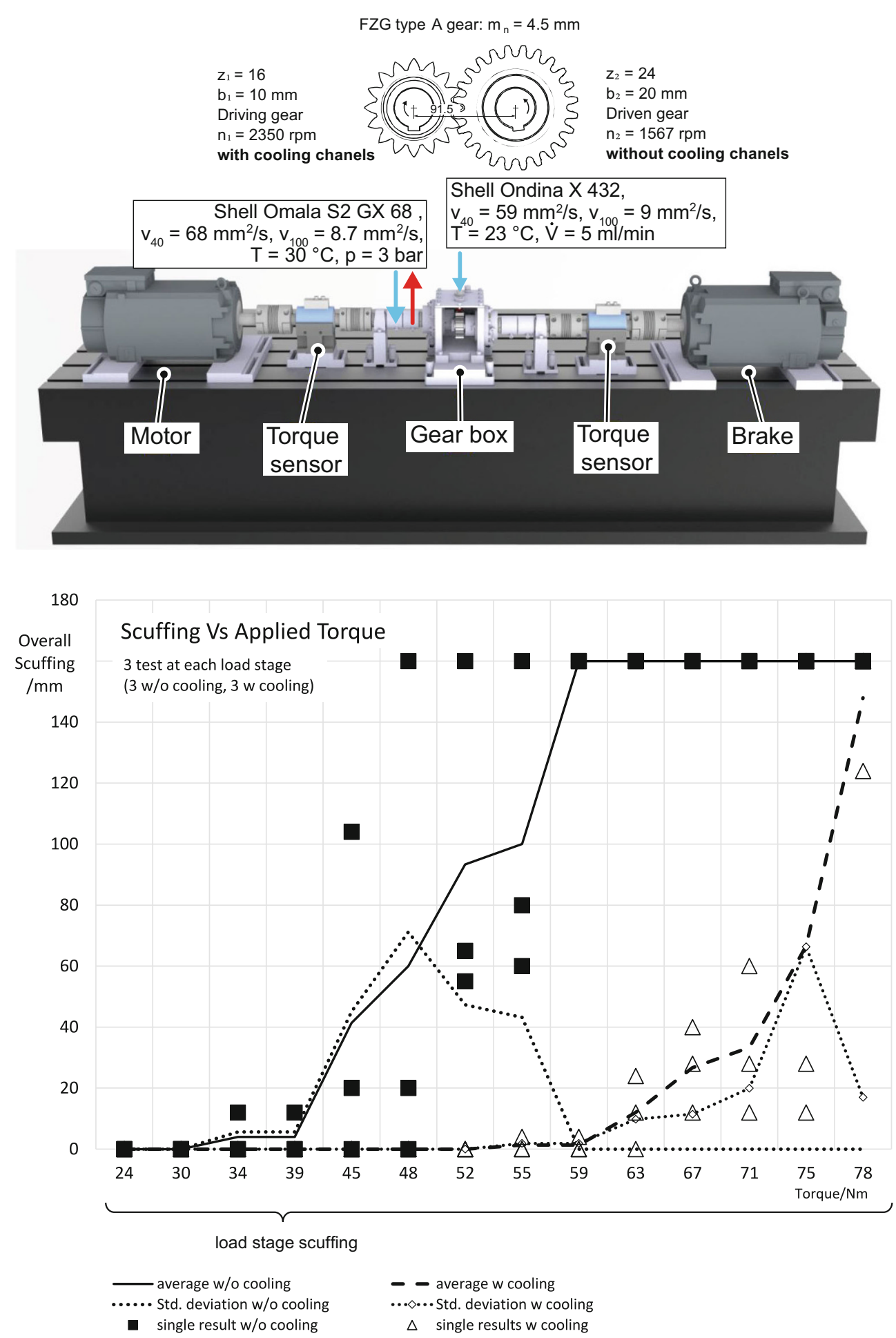

Therefore, at the highest possible power level achievable on the test bench, the safety against scuffing will possibly be too high for the internally cooled LPBF gears, which will prevent scuffing. Therefore, the safety against scuffing is estimated according to DIN 3990-4 [18] for various speeds and gear widths, and 14 load stages between 24 and
$78 \mathrm{Nm}$ were defined (cf. Fig. 10). These load stages are not comparable with those from DIN ISO 14635.

The gears are lubricated via minimum quantity lubrication from the top with $\dot{V}=5 \mathrm{ml} / \mathrm{min}$. An oil without additives is used to cause scuffing. This lubrication approach also deviates completely from DIN ISO 14635. Each load stage is operated for approximately $15 \mathrm{~min}$, and then the 

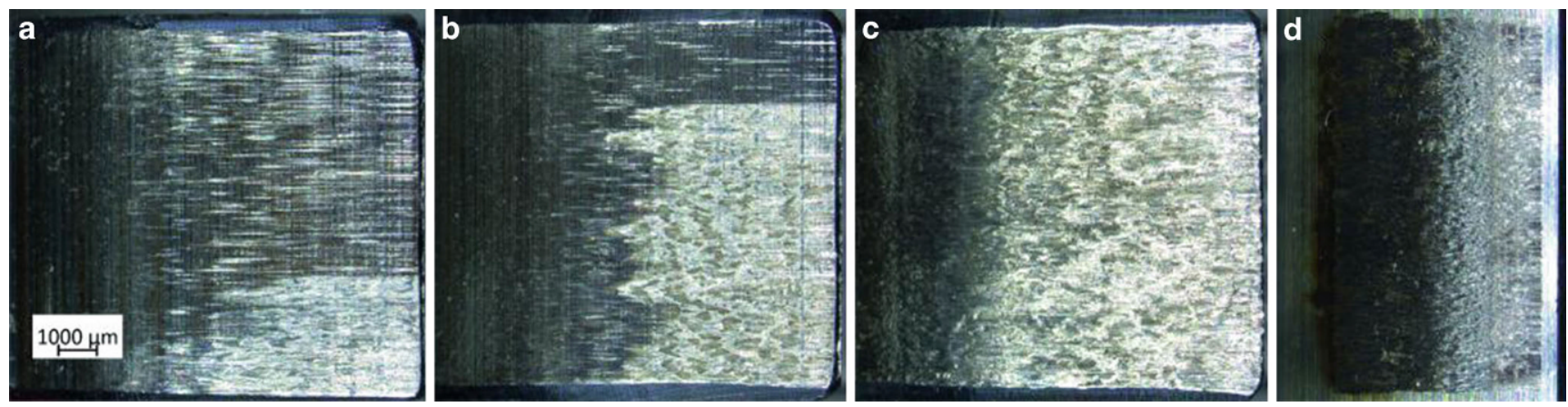

Fig. 11 Selection of damage patterns: a approximately $3 \mathrm{~mm}$ scuffing zone + scoring; $\mathbf{b}$ approximately $8 \mathrm{~mm}$ scuffing zone; $\mathbf{c} 10 \mathrm{~mm}$ wide damage (scuffing); d scuffed counter flank

contact pattern is analysed. The widths of the scuffing marks or areas are summed. With 16 teeth and a tooth width of $10 \mathrm{~mm}$, the maximum damage sum is $160 \mathrm{~mm}$. It is important that the analysis takes less than 3 min so that the gear does not cool down too much. If the damage sum is not reached, the load level is increased, and the test is run for approximately $15 \mathrm{~min}$ again. The tests were terminated at a damage sum of $160 \mathrm{~mm}$, not $20 \mathrm{~mm}$, as is the standard. The counter gear is also analysed but not included in the criteria.

\section{Results}

Fig. 10 shows the results of the six tests carried out (three with internal cooling and three without cooling). If the gears are not cooled from the inside, the scuffing starts at $34 \mathrm{Nm}$. The sum of $20 \mathrm{~mm}$ width of the scuff marks is reached at $45 \mathrm{Nm}$ and is fully developed at $59 \mathrm{Nm}$ at the end of the test. The magnitude is in the range of the safety against scuffing theoretically calculated with the integral temperature method.

However, if the gears are cooled from the inside, scuff marks first appear at $55 \mathrm{Nm}$, the sum of $20 \mathrm{~mm}$ forms at $63 \mathrm{Nm}$, and the fully developed scuff zone for all flanks forms at $78 \mathrm{Nm}$. Taking the damage sum of $20 \mathrm{~mm}$ as a reference, the cooled teeth are expected to increase safety against scuffing by approximately $30 \%$. Fig. 11 shows a selection of damage patterns. The rather asymmetrical distribution of the scuffing is due to cantilevered positioning in the test rig.

\section{Conclusion}

AM is being increasingly applied in numerous sectors, such as medical technology, aerospace, automotive and mechanical engineering, greatly extending its use [7]. However, AM is appropriate only if added value is generated. For example, cooling channels can be integrated into gears to increase safety against scuffing. Ideally, lubricant consumption can be reduced and efficiency increased as a result of better ventilation and splash losses. This is expected, especially in high-speed or turbo gearboxes. In this project, it was possible to manufacture gear wheels with internal cooling channels in powder form in a quenched and tempered 30CrNiMo8 steel (1.6580) and to demonstrate the added value by the increase in the safety factor against scuffing. In a parallel study, the tooth root strength of gears with integrated cooling channels is investigated. An FZG type $\mathrm{C}$ gear $(\mathrm{b}=7 \mathrm{~mm})$ with $2 \mathrm{~mm}$ diameter cooling channels was calculated and verified in the pulsator test. It is shown that the cycle numbers drop by up to $50 \%$ with such a small width. However, the influence of the diameter, position of the cooling channel coupled with different moduli and widths on the tooth root stress still needs to be investigated in detail.

In addition, the added value or the increase in efficiency must be considered in the overall energy consumption, which is not the content of this paper. Different cooling strategies and their production feasibility play a role here. For example, a parallel flow path is more efficient for heat transport, and it allows a more uniform flow. With a serial path, on the other hand, the powder can be removed more reliably, and the fluid can be guided more safely. This arrangement must be improved and further tested. In addition, it is very important to consider the total energy in future standardised tests of the safety against scuffing.

Funding We extend our sincere thanks to the Swiss Innovation Agency (Innosuisse) and the industry partner RENK-MAAG GmbH for funding and supporting this research within the research Grant 25648.1 PFIW-IW.

Funding Open access funding provided by ZHAW Zurich University of Applied Sciences

Conflict of interest H.-J. Dennig, L. Zumofen, D. Stierli, A. Kirchheim and S. Winterberg declare that they have no competing interests.

Open Access This article is licensed under a Creative Commons Attribution 4.0 International License, which permits use, sharing, adapta- 
tion, distribution and reproduction in any medium or format, as long as you give appropriate credit to the original author(s) and the source, provide a link to the Creative Commons licence, and indicate if changes were made. The images or other third party material in this article are included in the article's Creative Commons licence, unless indicated otherwise in a credit line to the material. If material is not included in the article's Creative Commons licence and your intended use is not permitted by statutory regulation or exceeds the permitted use, you will need to obtain permission directly from the copyright holder. To view a copy of this licence, visit http://creativecommons.org/licenses/by/4. $0 /$.

\section{References}

1. Kamps T (2018) Leichtbau von Stirnzahnrädern aus Einsatzstahl mittels Laserstrahlschmelzen. Dissertation, Technischen Universität München - Lehrstuhl für Betriebswissenschaften und Montagetechnik

2. Höller A, Huber F, Zumofen L et al (2021) Additive manufactured and topology optimized Flexpin for planetary gears. In: Meboldt M, Klahn C (eds) Industrializing additive manufacturing. Springer, Cham, pp 337-356

3. Wittel H, Jannasch D, Voßiek J et al (2019) Roloff /Matek Maschinenelemente: Normung, Berechnung, Gestaltung. Springer Vieweg, Wiesbaden

4. Niemann G, Winter H (2003) Maschinenelemente. Springer, Berlin, Heidelberg, New York

5. He B, Ying L, Li X, Hu P (2016) Optimal design of longitudinal conformal cooling channels in hot stamping tools. Appl Therm Eng 106:1176-1189. https://doi.org/10.1016/j.applthermaleng.2016.06. 113

6. Kirchheim A, Katrodiya Y, Zumofen L et al (2021) Dynamic conformal cooling improves injection molding: Hybrid molds manufactured by laser powder bed fusion. Int J Adv Manuf Technol. https://doi.org/10.1007/s00170-021-06794-0

7. Wohlers T, Campbell RI, Diegel O et al (2020) Wohlers report 2020: 3D printing and additive manufacturing state of the industry

8. Klocke F, Brecher C (2016) Zahnrad- und Getriebetechnik: Auslegung - Herstellung - Untersuchung - Simulation. Hanser, München

9. Mauz W (1988) Hydraulische Verluste von Stirnradgetrieben bei Umfangsgeschwindigkeiten bis $60 \mathrm{~m} / \mathrm{s}$. Dissertation, Universität Stuttgart

10. Siglmüller F, Kupfer S, Kamps T et al (2018) Efficiency of additive manufactured gears with conformal cooling

11. Fontana F, Leutenecker-Twelsiek B, Jansen J (2018) Entwicklung und Konstruktion für die Additive Fertigung: Grundlagen und Methoden für den Einsatz in industriellen Endkundenprodukten, 1st edn. Vogel Business Media, Würzburg

12. Adam GAO (2015) Systematische Erarbeitung von Konstruktionsregeln für die additiven Fertigungsverfahren Lasersintern, Laserschmelzen und Fused Deposition Modeling, 1st edn. Shaker, Aachen

13. Zumofen L, Beck C, Kirchheim A, Dennig H-J (2018) Quality related effects of the preheating temperature on laser melted high carbon content steels. In: Meboldt M, Klahn C (eds) Industrializing additive manufacturing-Proceedings of additive manufactur- ing in products and applications-AMPA2017. Springer, Cham, pp 210-219

14. Schmitt M, Kamps T, Siglmüller F et al (2020) Laser-based powder bed fusion of $16 \mathrm{MnCr} 5$ and resulting material properties. Addit Manuf 35:101372. https://doi.org/10.1016/j.addma.2020.101372

15. Bleck W, Moeller E (2018) Handbuch Stahl: Auswahl, Verarbeitung, Anwendung. Hanser, München

16. Deutsche Edelstahlwerke (2021) Cr-Ni-Mo-legierter Vergütungsstahl 1.6580, 30CrNiMo8. https://www.dew-stahl.com/fileadmin/files/ dew-stahl.com/documents/Publikationen/Werkstoffdatenblaetter/ Baustahl/1.6580_de.pdf. Accessed 12 Mar 2021

17. Ziebura D, Meiners W (2015) Verarbeitung von Einsatz- und Vergütungsstählen mittels SLM. Fraunhofer ILT,

18. DIN 3990-4: 1987-12, Tragfähigkeitsberechnung von Stirnrädern; Berechnung der Freßtragfähigkeit. Beuth Verlag GmbH

19. Bartz WJ (2010) Einführung in die Tribologie und Schmierungstechnik. expert, Renningen

20. DIN ISO 14635-1:2006-05, Zahnräder FZG-Prüfverfahren Teil_1: FZG-Prüfverfahren A/8,3/90 zur Bestimmung der relativen Fresstragfähigkeit von Schmierölen. Beuth Verlag $\mathrm{GmbH}$

21. Richard HA, Schramm B, Zipsner T (2017) Additive Fertigung von Bauteilen und Strukturen. Springer, Wiesbaden

22. Beismann H, Ossendoth U, Hermann M, Grunewald U (2015) Machbarkeitsstudie zur Optimierung der Kühlung von Formwerkzeugen durch bionische Methoden zur Erhöhung der Taktzahl bei der Ausformung von Produkten und damit einer Effizienzsteigerung zur Ressourcenschonung und Energieeinsparung (Abschlussbericht über ein Entwicklungsprojekt, gefördert unter dem Az: 30156/01 von der Deutschen Bundesstiftung Umwelt)

23. Stoll P, Leutenecker-Twelsiek B, Spierings A et al (2018) Temperature monitoring of an SLM part with embedded sensor. In: Meboldt M, Klahn C (eds) Industrializing additive manufacturing-Proceedings of additive manufacturing in products and applications-AMPA2017. Springer, Cham, pp 273-284

24. DIN EN 10083-3 Steels for quenching and tempering-Part 3: Technical delivery conditions for alloy steels. Deutsches Institut für Normung e. V., Berlin

25. Zumofen L, Kirchheim A, Dennig H-J (2020) Laser powder bed fusion of 30CrNiMo8 steel for quenching and tempering: examination of the processability and mechanical properties. Prog Addit Manuf 5:75-81. https://doi.org/10.1007/s40964-020-00121-x

26. Warlimont H, Martienssen W (2018) Springer handbook of materials data

27. Gebhardt A (2016) Additive Fertigungsverfahren: Additive Manufacturing und 3D-Drucken für Prototyping - Tooling - Produktion, 5 th edn. Hanser, München

28. VDI 3405:2015-12, Blatt 3 Additive Fertigungsverfahren - Konstruktionsempfehlungen für die Bauteilfertigung mit Laser-Sintern und Laser-Strahlschmelzen. Beuth Verlag, Berlin

29. Sehrt JT (2010) Möglichkeiten und Grenzen bei der generativen Herstellung metallischer Bauteile durch das Strahlschmelzverfahren. Shaker, Aachen

30. Jelis E, Clemente M, Kerwien S et al (2015) Metallurgical and mechanical evaluation of 4340 steel produced by direct metal laser sintering. JOM 67:582-589. https://doi.org/10.1007/s11837-0141273-8 